\title{
The Incidence of and Returns to 'Overeducation': PIAAC Evidence on the G7
}

\author{
Geraint Johnes ${ }^{1}$
}

\begin{abstract}
PIAAC data are used to evaluate the extent of overeducation in G7 countries. Incidence of overeducation is seen to vary systematically with a number of demographic characteristics. The impact of overeducation on remuneration is then estimated using quantile regression. This impact is observed to be minor, suggesting that while some individuals have qualifications in excess of those required to undertake their job, their additional human capital is nonetheless rewarded. Care therefore needs to be taken in interpreting measures of overeducation.
\end{abstract}

Keywords Overeducation · Rate of return · Underemployment · Mismatch

JEL Classification I21 $\cdot$ I26

\section{Introduction}

The concept of education as a right has a long history. In the 17 th century John Locke (1692: 29) argued that 'everyone's natural genius should be carried as far as it could'. While this view has been influential, it begs the question of how that 'genius' can be evaluated; how can learning be assigned a metric or a value? No doubt there are several dimensions that need to be considered. Amongst these are the contribution that learning can make to an individual's capacity to enjoy life, to

Geraint Johnes

G.Johnes@lancaster.ac.uk

1 Lancaster University Management School, Lancaster LA1 4YX, UK 
contribute to society, and to be economically productive. ${ }^{1}$ In all these respects, education represents an investment - the returns, whether they accrue to the individual or to society more broadly, come over a lengthy period following a transient upfront cost (of time and money).

A natural extension of this observation has been for economists to analyse education as an investment comparable to investments in physical capital that might be made by businesses. This involves the comparison of returns - appropriately discounted for time preference - with the upfront costs. In this respect, economists' analysis differs fundamentally from that of Locke; investment should continue only as long as the benefit net of costs is positive, not for as long as any (gross) benefit at all can be realised. ${ }^{2}$ If the gross benefit associated with education increases with the amount of schooling received, but does so at a diminishing rate, the possibility of an individual being overeducated - in the sense that the costs outweigh the benefits arises in the economists' analysis in a way that it would not arise for Locke. Taking into account the costs of education in this way makes overeducation possible even though an individual may be capable of learning more.

The argument for including costs in any consideration of the optimal level of education is compelling. However they are met - by the individual, by business sponsorship, or by government - these costs are a real resource that cannot then be spent on other things. The opportunity cost of tuition (whoever pays for it) is the output that teachers (and other school resources) and students alike could produce if they were employed in alternative activities. Locke's normative 'should', by ignoring these costs, encourages investing beyond the point at which the returns (in terms of happiness, contribution to society, and more narrowly defined pecuniary returns) justify the expenditure. Where, at the margin, the cost of an educational investment exceeds the benefits, it makes sense to describe a situation of overeducation.

In some cases, highly educated workers fail to gain employment in which their skills and those demanded by their employers are well matched. In such cases, the worker may be described as overeducated - though 'mismatch' may be a more accurate term, not least because this phenomenon is likely to describe a failure of the labour market rather than of the market for education. Nonetheless, we shall use the term 'overeducation' to describe this phenomenon in the present paper.

It is a phenomenon that is of considerable current interest. Turbulence can disturb the efficiency of mechanisms that allocate resources within an economy. One of the effects of the Great Recession of 2008-09 might therefore have been to perturb the matching technology by which workers are allocated to jobs, weakening the efficiency of this mechanism. Well qualified workers may, to a greater extent than in the past, be occupying positions in jobs that make less than full use of their

\footnotetext{
1 The positive relationship between happiness and education has been documented by many authors, including Blanchflower and Oswald (2011). Son and Wilson (2011), amongst many others, report a positive association between education and volunteering. The impact of education on economic productivity has been analysed in thousands of studies, with international evidence recently surveyed by Montenegro and Patrinos (2014). McMahon (2009) usefully reports evidence on wider benefits of education.

${ }^{2}$ Early contributions on the economics of human capital include Schultz (1961) and Becker (1964).
} 
productive potential. To the extent that their search for more appropriate employment is hamstrung by the costs of on-the-job search, this might be imposing a supply side constraint on the pace of recovery.

Fortuitously a new source of data offers the promise of throwing new light on this subject. The Organisation for Economic Cooperation and Development (OECD) has co-ordinated a survey, the Programme for International Assessment of Adult Competencies (PIAAC), that offers researchers an excellent opportunity to assess the stock and the use of skills across member states. The application of an identical survey across countries allows comparison across systems; this is particularly important in research contexts where the precise phrasing of questions across different surveys may subtly affect response. The aim of this paper is to use these PIAAC data to investigate a number of dimensions of the overeducation issue. In particular, we focus on the distributional issues, asking the research question: to what extent do the returns to surplus education vary across the distribution of workers? Confronting this question with data drawn from a number of countries is novel and is an important endeavour. While we know that rates of return to education - and to overeducation - vary across countries, and we also know that income distributions differ across countries, we have not till now known anything about how these effects interact. In particular, it is important to establish whether, lurking behind the averages, mismatch presents a particularly severe problem in certain contexts. It turns out that it does.

The term 'overeducation' is used in this paper while recognising that it is an example of loaded vocabulary. It is clearly closely related to 'underemployment' (in at least some of its forms) and, as noted above, to labour market mismatch. Green and McIntosh (2007) provide an excellent discussion of how mismatch can lead to employers complaining of skill shortages even while it is apparent that many workers possess qualifications in excess of those needed to do their work. Viewed from this perspective, measures that appear to reveal the considerable extent of overeducation rather betray a mix of poor reporting and inefficient allocation mechanisms in the labour market - and not necessarily a problem with education itself.

The remainder of the paper proceeds as follows. The next section briefly reviews the salient literature. This is followed by a section that describes the data used in the empirical analysis, then the empirical analysis itself, and then finally a conclusion.

\section{The Importance of Overeducation}

An early contribution to the literature on overeducation is that of Freeman (1976) who observed a declining rate of return to education over the early 1970s. ${ }^{3}$ This period coincided with a reduction in demand for highly educated scientists

\footnotetext{
3 The rate of return to education is the interest rate at which the present discounted value of the stream of future earnings premia due to education is brought equal to the cost of acquiring that education. A relatively high rate of return implies that education is highly remunerative. If the rate of return on education exceeds that which may be obtained on other investments (for example, if it exceeds the interest rate available on savings held in a bank), then education is a relatively worthwhile investment.
} 
following the Apollo landings and Vietnam war. As it turned out, the diminution of the rate of return proved to be ephemeral, but interest in the idea that the supply of highly educated labour could outstrip demand, thereby putting downward pressure on the relative wage paid to skilled workers, remained. In the United Kingdom, Brynin (2002) analysed data from both the Labour Force Survey and the British Household Panel Study, and found that increased graduate density (due to a higher proportion of young people undertaking higher education) lowered the gap between graduate and non-graduate earnings. Since the returns to education follow a distribution, some non-graduates earn more than graduates.

This literature has led to various approaches being taken to the study of overeducation, these being usefully surveyed by Groot and van den Brink (2000), McGuinness (2006), and Leuven and Oosterbeek (2011). The various approaches are all based on an attempt to identify the minimum educational requirements for each occupation, but they use different means to obtain this information. The various methods have produced markedly different estimates of the extent of the problem, and it is important therefore to understand the peculiarities of each.

The first method is based on direct inquiry of workers of the educational requirements associated with their job; many surveys include questions about this, and indeed this is the approach taken later in the present paper. Early examples of such an exercise include the work of Rumberger (1987) and Sicherman (1991), both of whom find evidence that the extent of overeducation was high in the USA at the time of their analysis. Sicherman, for instance, finds some $40 \%$ of workers to be overeducated. This figure, while high, is not out of line with findings from other time periods and other countries. Indeed, recent work by Holmes and Mayhew (2015:14), drawing upon the European Social Survey, reports that almost $60 \%$ of graduates in the UK are in non-graduate jobs; the proportion is yet higher in Greece and Estonia. ${ }^{4}$

The second method involves the use of administrative lists of occupational titles. For example, O*NET, sponsored by the US Department of Labor (http://www. onetonline.org/), provides a classification of occupations that is accompanied by information, for each occupation, on educational requirements. A typical example of the use of such data in the context of overeducation research is that of Van der Meer (2006), who, using two such measures, finds overeducation rates in the Netherlands in the region of $30 \%$.

A third approach, pioneered by Verdugo and Verdugo (1989) involves defining, for each occupation, required education by reference to the distribution, across workers, of educational attainment. If years of education are, say, one standard

\section{Footnote 3 continued}

Hence the falling rate of return observed by Freeman was a matter of concern; a rate of return falling below that obtainable from alternative investments suggested that (based on the evidence of the observable economic data) too much resource was being invested in education and not enough elsewhere.

${ }^{4}$ Further influential examples of this approach include Dolton and Vignoles (2000) and Dolton and Silles (2008). The latter paper highlights the sensitivity of estimates of overeducation to the precise question asked of respondents - specifically whether they are asked about the level of education required to $d o$ a job or to get a job. Another recent exercise has been conducted by Foley and Brinkley (2015), again finding high incidence of overeducation in the UK. 
deviation or more above the mean for the occupation in question, then a worker is said to be overeducated. This approach has obvious appeal in instances where a direct measure of job requirements is absent. It has, however, been widely criticised in the literature, not least because of the arbitrary nature of the one standard deviation cut-off point (Leuven and Oosterbeek 2011), and because (since the mean changes) it does not permit analysis over time or across cohorts (Flisi et al. 2014). The method has typically yielded estimates of overeducation that are somewhat lower than those obtained using the other approaches.

It should be noted that a degree of arbitrariness surrounds any measure of required education obtained by the above methods. Many occupations could be undertaken, albeit not very well and at low levels of productivity, by minimally educated workers. The definition of a minimum acceptable level of productivity in each occupation is essentially arbitrary. A good discussion of these issues is provided by Green et al. (1999). Inevitably then, researchers are left to employ a working definition that is not altogether satisfactory. The high estimates of the rate of overeducation observed in some studies - including this one - should be viewed with this in mind. This being the case, comparison of rates of overeducation (or underemployment, or mismatch) across demographic groups or across time is likely to be a more useful exercise than any focus on the absolute level.

Further caution in interpreting apparently high rates of overeducation at face value comes in the work of Duncan and Hoffman (1981), who revisit Freeman's approach by investigating the way in which overeducation affects the rate of return to schooling. They find that workers whose educational attainment exceeds that required for their job earn a positive rate of return on those years of schooling that are surplus to those required for the job, though this rate is lower than that associated with their schooling up to the required level. This finding begs the question: if the rate of return on surplus schooling exceeds the external rate of return that may be earned (for example) by depositing money in a bank, the term 'overeducation' may itself be a misnomer - even when defined in narrow economic terms. It is also consistent with the definition of a required level of educational attainment for each occupation being an arbitrary judgement often at odds with the statistical evidence on how, within a given occupation, education affects productivity. ${ }^{5}$ In a recent paper, Abel and Deitz (2016) have directly investigated the skill content of jobs occupied by US college graduates who have self-identified as underemployed; they find that while $45 \%$ of graduates deem themselves to be underemployed, fewer than $10 \%$ are in low-skilled service jobs. Subjective measures of underemployment, or overeducation, seem therefore to be upwardly biased.

Evidence on the rate of return to education (for example, Walker and Zhu 2011) confirms that, in the UK as in other developed economies, this return remains fairly high. To be sure, such estimates are based on the experience of the average graduate, and are not necessarily consistent with the experience of prospective

\footnotetext{
5 In the years following publication of Duncan and Hoffman's paper, several further studies likewise examined the returns associated with overeducation. A notable example is that of Borghans and de Grip (1999), which in turn draws on the work of Hartog (1985) that uses concepts of overeducation in an attempt to evaluate human capital theory.
} 
students who are at the margin of deciding whether or not to continue in education. This question has, however, been addressed through the estimation of quantile regressions which suggest that it is uncommon, even at the lowest deciles of the distribution, for the rate of return to education to fall below the external rate of return (Martins and Pereira 2004). ${ }^{6}$ Using a similar approach, Bender and Roche (2017) analyse US data, and show that, particularly for those whose jobs and qualifications are severely mismatched, the penalty attached to overeducation is greatest for those at the lower end of the wage distribution.

To summarise, discussion of overeducation has focused largely on issues of match in the labour market. Where an individual has been educated up to a level that exceeds that required for the job, that individual is said to be overeducated. But the required level is an arbitrary construct, demonstrably so since we know that workers earn high returns on their surplus education (albeit not as high as on their required education). We also know that, of the UK respondents to PIAAC that report themselves to be overeducated, the vast majority do, at least to some extent, use advanced skills in their work. ${ }^{7}$ Nonetheless, since returns do fall somewhat once the required education threshold is passed, the threshold - and so the concept of overeducation - is meaningful. Workers who are currently in jobs for which some of their education is surplus to requirements could likely earn higher returns in more demanding occupations. Surplus education reflects an investment that may be performing well relative to investments outside the sphere of education, but less well than educational investments where workers succeed in efficiently matching their skills and occupations. Moreover, even where the returns to surplus education are, on average, positive, heterogeneity of experience across individuals may well mean that for some workers the surplus education represents a poor investment.

In the remainder of the paper, we use a new data set to throw light on the issue of overeducation, interpreted in this way, in major economies of the world.

\section{Data}

PIAAC provides an immensely rich set of information on individuals' education, skills and work experience. This data set has the considerable advantage of providing, in a standard format, data across a large number of developed countries. ${ }^{8}$

\footnotetext{
${ }^{6}$ The issue of heterogeneity is shown to be important by Maier et al. (2003), who find that while, for the typical overeducated worker, the returns to overeducation are positive, there is considerable variation across individuals. Other work using quantile regression approaches includes Gaeta et al. (2018) which focuses specifically on Italian PhD holders.

${ }^{7}$ Advanced skills are here defined by writing or reading reports and/or articles, calculating costs or budgets, preparing graphs or tables, using simple algebra or more advanced maths/statistics. While the PIAAC data sets contain direct measures of certain skills obtained by testing respondents, we deem measures the skills that are actually used at work to be more pertinent in the determination of labour market outcomes.

${ }^{8}$ The PIAAC data have previously been used to examine overeducation, a notable study being that of Flisi et al. (2014). An analysis specific to one country, namely Spain, by Nieto (2014), has in common with the present study the estimation of wage equations; qualitatively her findings are similar to those reported in the sequel.
} 
To focus specifically on major economies, we examine data for the G7 countries with the exception of Canada (where, for reasons of data availability, it is not possible to construct an indicator for overeducation). In each country, PIAAC gathers data on at least 4,500 respondents, all aged between 16 and 65, but since some of these are not in work at the time of the survey the sample size used in the present analysis is somewhat smaller. The data collection method used in each country resulted in samples that mirror the population imperfectly; this feature is corrected in the present analysis by weighting the data appropriately, using weights provided in PIAAC itself. The results reported below are therefore based on samples representative of the population of 16-65 year olds within each country.

The countries included in the present study all participated in the first round of PIAAC, for which data were collected between 1 August 2011 and 31 March 2012. The data of interest concern individual respondents, and these are surveyed at just one point in time, thus providing a cross-section of data. The absence of longitudinal data at the level of the individual precludes the use of fixed (or random) effects models to control for time-invariant unobserved factors.

We define an individual to be overeducated if they have qualifications at a higher level than those that the individuals themselves report as being required for their job, or if they meet the qualification requirement exactly but deem the requirement to be a higher level of education than is actually needed to do the job. ${ }^{9}$ Note that interpretation of the measure of overeducation derived in this way is subject to the observation that job requirements are, to some extent at least, arbitrary. Our main focus in the sequel, however, is on how this measure varies across countries and across demographics within each country; assuming any bias in the measure itself to be given, examination of variations across groups remains instructive.

\section{Empirical Analysis}

In the top row of Table 1, the percentage of individuals in work who are overeducated in their current job is reported for each of the six countries under study. There is some variation across countries, with Italy standing out as having a smaller proportion than elsewhere of the working population reporting themselves to be overeducated. ${ }^{10}$

\footnotetext{
9 To be specific, this involves comparison of the responses to the following questions: 'Which of the qualifications on this card is the highest you have obtained?'; 'Still talking about your current job: if applying today, what would be the usual qualifications, if any, that someone would need to get this type of job?'; 'Thinking about whether this qualification is necessary for doing your job satisfactorily, which of the following statements would be most true?'. Note that, if the answer to the last of these is: 'a lower level would be sufficient', the individual is deemed overeducated if he or she has exactly the usual qualifications required to get the job. Other measures of overeducation may be derived from the PIAAC data. Flisi et al. (2014) provide a comparison.

${ }^{10}$ Brynin and Longhi (2009) likewise find evidence of a relatively low incidence of overeducation in Italy, and it appears that the difference between Italy and other countries is concentrated at the lower end of the distribution of educational attainment. Pastore (2017) has documented the difficult and prolonged nature of the school-to-work transition in Italy, and - given the impact that this has on actual work experience at any given age - this may contribute to explaining the low rate of self-reported
} 
Table 1 Percent overeducated, total and by subgroup

\begin{tabular}{|c|c|c|c|c|c|c|}
\hline & UK & Germany & France & Italy & Japan & USA \\
\hline Overeducated & 50.7 & 42.5 & 53.5 & 34.1 & 52.1 & 49.6 \\
\hline Male & 48.0 & 38.9 & 53.3 & 31.8 & 54.8 & 49.5 \\
\hline Female & 52.0 & 45.9 & 53.7 & 36.2 & 49.7 & 49.7 \\
\hline Managerial/professional/technical & 48.4 & 36.7 & 39.1 & 17.8 & 40.4 & 46.6 \\
\hline Clerical & 48.7 & 43.9 & 54.7 & 24.9 & 57.2 & 52.7 \\
\hline Sales & 54.5 & 50.7 & 69.7 & 54.8 & 58.2 & 52.0 \\
\hline Manual & 47.7 & 45.6 & 71.7 & 52.1 & 61.7 & 53.3 \\
\hline Higher education & 68.1 & 43.8 & 44.0 & 33.8 & 58.4 & 58.5 \\
\hline Upper secondary & 50.6 & 43.3 & 55.4 & 31.3 & 48.1 & 40.9 \\
\hline Lower secondary & 55.4 & 33.5 & 63.1 & 39.5 & 38.9 & 46.0 \\
\hline Arts specialism & 52.7 & 39.0 & 55.1 & 33.5 & 55.5 & 60.8 \\
\hline Social science specialism & 59.2 & 49.1 & 55.7 & 36.6 & 61.2 & 56.2 \\
\hline Science specialism & 53.9 & 39.8 & 50.4 & 33.2 & 57.3 & 52.6 \\
\hline Medical specialism & 41.5 & 31.1 & 42.0 & 15.7 & 30.6 & 50.6 \\
\hline Tenure up to 5 years with current employer & 57.0 & & 59.8 & 47.8 & 55.3 & \\
\hline Tenure over 5 years with current employer & 45.0 & & 49.4 & 27.1 & 49.6 & \\
\hline Age 16-24 & 58.9 & & 65.2 & 54.2 & 50.3 & \\
\hline Age $25-49$ & 53.3 & & 54.8 & 36.2 & 52.9 & \\
\hline Age $50+$ & 39.9 & & 47.5 & 26.3 & 51.5 & \\
\hline Supervisory responsibility & 50.6 & 35.3 & 42.3 & 19.2 & 47.2 & 47.1 \\
\hline Firm size $1-10$ & 53.5 & 45.6 & 59.7 & 45.2 & 55.7 & 54.4 \\
\hline Firm size $11-50$ & 51.2 & 44.3 & 56.1 & 30.6 & 52.8 & 49.3 \\
\hline Firm size $51-250$ & 49.0 & 38.7 & 52.2 & 29.8 & 52.9 & 51.4 \\
\hline Firm size $251-1000$ & 50.2 & 41.7 & 47.5 & 21.4 & 46.2 & 43.6 \\
\hline Firm size over 1000 & 45.9 & 40.7 & 38.8 & 19.7 & 43.8 & 46.8 \\
\hline Native & 51.1 & 41.8 & 53.1 & 29.2 & 52.2 & 49.6 \\
\hline Parent with higher education & 48.4 & 44.1 & 52.3 & 34.5 & 51.3 & 50.8 \\
\hline
\end{tabular}

Continuous data for age and tenure are not available for Germany and the USA, these variables being measured in bands for these countries. Data for the subgroup representing those with (at most) "primary or no formal qualifications' are not reported owing to small numbers of observations in this subgroup

The incidence of overeducation, on this measure, is high. Indeed, in three of the countries (slightly) more than $50 \%$ of workers report that they are overeducated, and even in Italy the incidence of overeducation exceeds one third. The lower incidence of overeducation observed in Italy is consistent with evidence on labour market matching; for instance, the OECD (2012: 34) reports that the Beveridge curve,

Footnote 10 continued

overeducation in this country. At degree level, meanwhile, Brynin and Longhi find little variation across countries, and this likely explains why other studies focusing on Italy have not identified unusually low rates of overeducation when focusing on graduate level data (see, for example, Gaeta 2015; Caroleo and Pastore 2017). 
which plots vacancy rates against unemployment rates at different points in time, is closer to the origin - indicating a more effective matching technology between unemployment and vacancies - in Italy than in many other countries. While many respondents doubtless do not use everything they learned in their highest level of education, the broader set of skills they required at that level is indeed relevant to their job. Thus the absolute value of this measure is less informative than the way in which the measure varies across demographics.

The remaining rows of Table 1 report the incidence of overeducation amongst various subgroups. There turns out to be considerable variation between these groups, even within one country. For example, in Italy, more than half of young workers (aged 16-24), but only $26 \%$ of older workers (aged 50 or above), are overeducated. ${ }^{11}$ The longer workers are in the labour market, the more opportunity they have to change jobs and secure a better match between their skills and the demands of their occupation. This effect is apparent in all countries studied here, but appears to be much stronger in Italy than elsewhere.

The incidence of overeducation appears to fall, albeit not monotonically in every country, as occupational status rises. This result is unsurprising as it is less likely that workers in more demanding roles are overprepared for those roles. The variation across occupations is particularly pronounced in France and Italy. This may in part reflect the timing of the survey; for most countries, the data were collected in late 2011 and early 2012, though in France they were collected later in 2012. Both Italy and France were slower than other countries in our analysis to recover from the 2008-09 recession, and they were, at the time that the PIAAC data were collected, the countries with the highest unemployment rates, and were also the only countries in which unemployment was still rising.

Just as overeducation is least likely for those in the least demanding occupations, it is most likely to be observed amongst those with the strongest background of educational qualifications. Again the relationship is not monotonic, and indeed it is reversed in the case of France. For those who reached a level of education at which they specialised in one subject, overeducation is least prevalent amongst those who studied medicine - a subject that has a highly vocational orientation. In most countries it is highest for those who studied the social sciences.

Tenure with the current employer is negatively associated with overeducation. This may be because employers learn about their workers' skills over time, and so workers gradually move to positions within the firm that suit their capabilities. Or it might be that, where the mismatch between worker and firm is severe, workers tend to leave the firm after a relatively short period. The direction of causality is therefore unclear, with both arguments reinforcing the negative association between tenure and overeducation. Likewise, there is (in most countries) a negative relationship between workers' age and overeducation. This may reflect a tendency

\footnotetext{
11 The education levels attained by the adult population in Italy is much lower than in the other countries studied here, making overeducation relatively unlikely in that country (OECD 2016, Table A.1.1). Other work in the Italian context emphasises that overeducation is a relatively new phenomenon in that country, affecting recent graduates rather than the population across the whole age distribution (Di Pietro and Urwin 2006). Furthermore, it is likely that examining overeducation at national level conceals significant regional differentials in Italy (Iammarino and Marinelli 2015).
} 
for workers to find appropriate employment over time. It may, equally, however, reflect a cohort effect whereby more recent cohorts of entrants to the labour market are more likely than earlier cohorts to be overeducated. Unfortunately, without access to panel data, it is difficult to see how these two effects can be disentangled.

Workers with supervisory responsibilities are less likely to be overeducated than others. This effect is particularly strong in Italy.

There is some evidence of a firm size effect, with the incidence of overeducation falling as company size increases. This might reflect a tendency for larger firms to be able to employ a more efficient division of labour, employing specialists solely to undertake specialist duties. This reduces the incidence of mismatch. The finding might also reflect the efficiency of human resource management mechanisms in larger firms.

With one important exception, immigration has little impact on the likelihood with which an individual is overeducated. In Italy, however, native workers are markedly less likely than the population as a whole to report themselves as being overeducated.

Finally, parental education (as measured by an indicator that at least one parent has experienced higher education) has no systematic effect on an individual's propensity to be overeducated.

The above consideration of descriptive statistics is helpful in highlighting broad patterns in the data, but a more rigorous treatment allows us to identify which patterns are statistically significant. To this end, panels A and B of Table 2 report marginal effects obtained by logit analyses of a model that links the various explanatory variables identified above to the dependent variable of overeducation. ${ }^{12}$ The two panels of this table differ in the handling of higher education as an explanatory variable - in panel A, higher education appears as a binary variable, while in panel B there are binary variables for each subject specialism at this level of education.

While the results obtained using this analysis are broadly in line with those that emerge from inspection of the descriptive statistics, some patterns are worthy of particular emphasis.

One of the puzzles that emerged from the earlier analysis was the reversal, in the case of France, of the common finding that overeducation rises with the level of education. The logit results in panel A throw some light on this. Relative to the excluded category (no qualifications) ${ }^{13}$, it is the case that in France, as elsewhere, education raises the likelihood of being overeducated. Nevertheless, there does

\footnotetext{
12 The logit model is due to Berkson (1944), and has been extensively used since. It provides a means of statistically estimating the parameters of an equation where the dependent variable is binary. Least squares regression is not appropriate in this context because we wish to constrain predicted values of the dependent variable to the unit interval. The logit method achieves this by modelling a latent variable that lies between $-\infty$ and $\infty$, and transforming this variable so that values that lie above or below a cutoff correspond to values of 1 or 0 of the binary variable. The marginal effects reported in the table are evaluated at mean values of the explanatory variables, and indicate the impact of a marginal change in the corresponding variable on the likelihood of an individual being overeducated.

13 One of the education categories has to be excluded from the vector of explanatory variables used in the logit analysis; otherwise the sum of the dummy variables representing the various levels of education would equal one, and this would result in perfect collinearity with the constant term in the equation. This collinearity would render the model intractable.
} 
Table 2 Logit results on overeducation: marginal effects

\begin{tabular}{|c|c|c|c|c|c|c|}
\hline & UK & Germany & France & Italy & Japan & USA \\
\hline \multicolumn{7}{|l|}{ Panel A } \\
\hline Managerial/professional/technical & $\begin{array}{l}-0.1944 \\
(4.05)^{*}\end{array}$ & $\begin{array}{l}-0.1848 \\
(6.74)^{*}\end{array}$ & $\begin{array}{l}-0.2787 \\
(10.74)^{*}\end{array}$ & $\begin{array}{l}-0.4064 \\
(11.84)^{*}\end{array}$ & $\begin{array}{l}-0.3651 \\
(13.92)^{*}\end{array}$ & $\begin{array}{l}-0.2469 \\
(7.36)^{*}\end{array}$ \\
\hline Clerical & $\begin{array}{l}-0.1461 \\
(2.91)^{*}\end{array}$ & $\begin{array}{l}-0.0688 \\
(2.24)^{*}\end{array}$ & $\begin{array}{l}-0.1663 \\
(4.82)^{*}\end{array}$ & $\begin{array}{l}-0.2439 \\
(9.33)^{*}\end{array}$ & $\begin{array}{l}-0.1096 \\
(3.33)^{*}\end{array}$ & $\begin{array}{l}-0.0741 \\
(1.65)\end{array}$ \\
\hline Sales & $\begin{array}{l}-0.0296 \\
(0.63)\end{array}$ & $\begin{array}{l}-0.0007 \\
(0.02)\end{array}$ & $\begin{array}{l}-0.0334 \\
(0.99)\end{array}$ & $\begin{array}{l}-0.0608 \\
(1.81)\end{array}$ & $\begin{array}{l}-0.0674 \\
(2.28)^{*}\end{array}$ & $\begin{array}{l}-0.0367 \\
(1.07)\end{array}$ \\
\hline Supervisor & $\begin{array}{l}0.0120 \\
(0.32)\end{array}$ & $\begin{array}{l}-0.0889 \\
(4.09)^{*}\end{array}$ & $\begin{array}{l}-0.0650 \\
(2.96)^{*}\end{array}$ & $\begin{array}{l}-0.0932 \\
(3.06)^{*}\end{array}$ & $\begin{array}{l}-0.0152 \\
(0.64)\end{array}$ & $\begin{array}{l}-0.0171 \\
(0.70)\end{array}$ \\
\hline Firm size $11-50$ & $\begin{array}{l}-0.0395 \\
(0.92)\end{array}$ & $\begin{array}{l}-0.0056 \\
(0.21)\end{array}$ & $\begin{array}{l}0.0236 \\
(0.89)\end{array}$ & $\begin{array}{l}-0.0170 \\
(0.54)\end{array}$ & $\begin{array}{l}-0.0498 \\
(1.92)\end{array}$ & $\begin{array}{l}-0.0760 \\
(2.43)^{*}\end{array}$ \\
\hline Firm size $51-250$ & $\begin{array}{l}-0.0361 \\
(0.76)\end{array}$ & $\begin{array}{l}-0.0500 \\
(1.77)\end{array}$ & $\begin{array}{l}-0.0073 \\
(0.26)\end{array}$ & $\begin{array}{l}0.0064 \\
(0.18)\end{array}$ & $\begin{array}{l}-0.0367 \\
(1.30)\end{array}$ & $\begin{array}{l}-0.0702 \\
(2.16)^{*}\end{array}$ \\
\hline Firm size $251-1000$ & $\begin{array}{l}-0.0087 \\
(0.15)\end{array}$ & $\begin{array}{l}-0.0083 \\
(0.26)\end{array}$ & $\begin{array}{l}-0.0381 \\
(1.19)\end{array}$ & $\begin{array}{l}-0.0913 \\
(2.04)^{*}\end{array}$ & $\begin{array}{l}-0.0976 \\
(2.82)^{*}\end{array}$ & $\begin{array}{l}-0.1425 \\
(3.96) *\end{array}$ \\
\hline Firm size over 1000 & $\begin{array}{l}-0.0948 \\
(1.54)\end{array}$ & $\begin{array}{l}-0.0183 \\
(0.50)\end{array}$ & $\begin{array}{l}-0.0857 \\
(2.28)^{*}\end{array}$ & $\begin{array}{l}-0.0534 \\
(0.98)\end{array}$ & $\begin{array}{l}-0.1069 \\
(2.44)^{*}\end{array}$ & $\begin{array}{l}-0.1295 \\
(3.34)^{*}\end{array}$ \\
\hline Native & $\begin{array}{l}0.1303 \\
(1.88)\end{array}$ & $\begin{array}{l}-0.0568 \\
(1.72)\end{array}$ & $\begin{array}{l}-0.0192 \\
(0.58)\end{array}$ & $\begin{array}{l}-0.2335 \\
(4.87)^{*}\end{array}$ & $\begin{array}{l}-0.2263 \\
(1.31)\end{array}$ & $\begin{array}{l}0.0029 \\
(0.09)\end{array}$ \\
\hline Parental education & $\begin{array}{l}-0.1172 \\
(2.39)^{*}\end{array}$ & $\begin{array}{l}0.0266 \\
(1.26)\end{array}$ & $\begin{array}{l}-0.0127 \\
(0.47)\end{array}$ & $\begin{array}{l}0.0126 \\
(0.22)\end{array}$ & $\begin{array}{l}-0.0443 \\
(1.98)^{*}\end{array}$ & $\begin{array}{l}-0.0115 \\
(0.48)\end{array}$ \\
\hline Experience & $\begin{array}{l}0.0005 \\
(0.31)\end{array}$ & $\begin{array}{l}-0.0019 \\
(2.37)^{*}\end{array}$ & $\begin{array}{l}-0.0020 \\
(1.85)\end{array}$ & $\begin{array}{l}-0.0032 \\
(1.96)^{*}\end{array}$ & $\begin{array}{l}-0.0008 \\
(0.77)\end{array}$ & $\begin{array}{l}0.0006 \\
(0.68)\end{array}$ \\
\hline Tenure & $\begin{array}{l}-0.0039 \\
(1.89)\end{array}$ & & $\begin{array}{l}-0.0043 \\
(3.56)^{*}\end{array}$ & $\begin{array}{l}-0.0049 \\
(2.77)^{*}\end{array}$ & $\begin{array}{l}-0.0025 \\
(2.18)^{*}\end{array}$ & \\
\hline Lower secondary & $\begin{array}{l}0.5424 \\
(10.00)^{*}\end{array}$ & $\begin{array}{l}-0.2273 \\
(1.99)^{*}\end{array}$ & $\begin{array}{l}0.6158 \\
(6.83)^{*}\end{array}$ & & & \\
\hline Upper secondary & $\begin{array}{l}0.5137 \\
(9.26)^{*}\end{array}$ & $\begin{array}{l}-0.0886 \\
(0.58)\end{array}$ & $\begin{array}{l}0.5029 \\
(8.19)^{*}\end{array}$ & $\begin{array}{l}0.1016 \\
(2.85)^{*}\end{array}$ & $\begin{array}{l}0.1440 \\
(5.13)^{*}\end{array}$ & $\begin{array}{l}0.0165 \\
(0.38)\end{array}$ \\
\hline Higher education & $\begin{array}{l}0.5844 \\
(16.73)^{*}\end{array}$ & $\begin{array}{l}0.0191 \\
(0.12)\end{array}$ & $\begin{array}{l}0.5813 \\
(5.87)^{*}\end{array}$ & $\begin{array}{l}0.3485 \\
(6.17)^{*}\end{array}$ & $\begin{array}{l}0.3837 \\
(14.33)^{*}\end{array}$ & $\begin{array}{l}0.3272 \\
(7.63)^{*}\end{array}$ \\
\hline Male & $\begin{array}{l}-0.0480 \\
(1.37)\end{array}$ & $\begin{array}{l}-0.0720 \\
(3.45)^{*}\end{array}$ & $\begin{array}{l}0.0107 \\
(0.53)\end{array}$ & $\begin{array}{l}-0.0465 \\
(1.62)\end{array}$ & $\begin{array}{l}0.1284 \\
(6.04)^{*}\end{array}$ & $\begin{array}{l}-0.0050 \\
(0.22)\end{array}$ \\
\hline $\mathrm{N}$ & 3109 & 3269 & 3475 & 2051 & 3313 & 2841 \\
\hline Log-pseudolikelihood & -3.61 & -0.26 & -0.41 & -0.21 & -0.15 & -0.06 \\
\hline \multicolumn{7}{|l|}{ Panel B } \\
\hline Managerial/professional/technical & $\begin{array}{l}-0.0181 \\
(0.39)\end{array}$ & $\begin{array}{l}-0.1895 \\
(6.63)^{*}\end{array}$ & $\begin{array}{l}-0.2730 \\
(10.46)^{*}\end{array}$ & $\begin{array}{l}-0.3328 \\
(10.48)^{*}\end{array}$ & $\begin{array}{l}-0.2288 \\
(8.67)^{*}\end{array}$ & $\begin{array}{l}-0.2235 \\
(6.83)^{*}\end{array}$ \\
\hline Clerical & $\begin{array}{l}-0.0405 \\
(0.84)\end{array}$ & $\begin{array}{l}-0.1180 \\
(3.80)^{*}\end{array}$ & $\begin{array}{l}-0.1614 \\
(4.65)^{*}\end{array}$ & $\begin{array}{l}-0.2265 \\
(8.13)^{*}\end{array}$ & $\begin{array}{l}-0.0410 \\
(1.28)\end{array}$ & $\begin{array}{l}-0.0554 \\
(1.22)\end{array}$ \\
\hline Sales & $\begin{array}{l}0.0503 \\
(1.18)\end{array}$ & $\begin{array}{l}-0.0233 \\
(0.75)\end{array}$ & $\begin{array}{l}-0.0245 \\
(0.72)\end{array}$ & $\begin{array}{l}-0.0543 \\
(1.57)\end{array}$ & $\begin{array}{l}-0.0185 \\
(0.65)\end{array}$ & $\begin{array}{l}-0.0262 \\
(0.75)\end{array}$ \\
\hline
\end{tabular}


Table 2 continued

\begin{tabular}{|c|c|c|c|c|c|c|}
\hline & UK & Germany & France & Italy & Japan & USA \\
\hline Supervisor & $\begin{array}{l}0.0451 \\
(1.27)\end{array}$ & $\begin{array}{l}-0.0904 \\
(4.09)^{*}\end{array}$ & $\begin{array}{l}-0.0575 \\
(2.59)^{*}\end{array}$ & $\begin{array}{l}-0.0834 \\
(2.73)^{*}\end{array}$ & $\begin{array}{l}-0.0086 \\
(0.37)\end{array}$ & $\begin{array}{l}-0.0123 \\
(0.51)\end{array}$ \\
\hline Firm size $11-50$ & $\begin{array}{l}-0.0067 \\
(0.17)\end{array}$ & $\begin{array}{l}-0.0072 \\
(0.26)\end{array}$ & $\begin{array}{l}0.0305 \\
(1.15)\end{array}$ & $\begin{array}{l}-0.0163 \\
(0.50)\end{array}$ & $\begin{array}{l}-0.0416 \\
(1.64)\end{array}$ & $\begin{array}{l}-0.0695 \\
(2.19)^{*}\end{array}$ \\
\hline Firm size $51-250$ & $\begin{array}{l}-0.0227 \\
(0.49)\end{array}$ & $\begin{array}{l}-0.0494 \\
(1.74)\end{array}$ & $\begin{array}{l}0.0023 \\
(0.08)\end{array}$ & $\begin{array}{l}0.0186 \\
(0.51)\end{array}$ & $\begin{array}{l}-0.0090 \\
(0.33)\end{array}$ & $\begin{array}{l}-0.0604 \\
(1.83)\end{array}$ \\
\hline Firm size $251-1000$ & $\begin{array}{l}0.0125 \\
(0.24)\end{array}$ & $\begin{array}{l}-0.0153 \\
(0.47)\end{array}$ & $\begin{array}{l}-0.0215 \\
(0.66)\end{array}$ & $\begin{array}{l}-0.0811 \\
(1.71)\end{array}$ & $\begin{array}{l}-0.0744 \\
(2.15)^{*}\end{array}$ & $\begin{array}{l}-0.1277 \\
(3.55)^{*}\end{array}$ \\
\hline Firm size over 1000 & $\begin{array}{l}-0.0292 \\
(0.49)\end{array}$ & $\begin{array}{l}-0.0251 \\
(0.67)\end{array}$ & $\begin{array}{l}-0.0574 \\
(1.49)\end{array}$ & $\begin{array}{l}-0.0324 \\
(0.58)\end{array}$ & $\begin{array}{l}-0.0915 \\
(2.10)^{*}\end{array}$ & $\begin{array}{l}-0.1142 \\
(2.92)^{*}\end{array}$ \\
\hline Native & $\begin{array}{l}0.0799 \\
(1.28)\end{array}$ & $\begin{array}{l}-0.0682 \\
(2.05)^{*}\end{array}$ & $\begin{array}{l}-0.0087 \\
(0.27)\end{array}$ & $\begin{array}{l}-0.2631 \\
(5.40)^{*}\end{array}$ & $\begin{array}{l}-0.1941 \\
(1.00)\end{array}$ & $\begin{array}{l}0.0123 \\
(0.37)\end{array}$ \\
\hline Parental education & $\begin{array}{l}-0.0804 \\
(1.64)\end{array}$ & $\begin{array}{l}0.2267 \\
(1.25)\end{array}$ & $\begin{array}{l}-0.0229 \\
(0.84)\end{array}$ & $\begin{array}{l}0.0597 \\
(1.02)\end{array}$ & $\begin{array}{l}-0.0040 \\
(0.19)\end{array}$ & $\begin{array}{l}-0.0005 \\
(0.02)\end{array}$ \\
\hline Experience & $\begin{array}{l}-0.0019 \\
(1.27)\end{array}$ & $\begin{array}{l}-0.0013 \\
(1.62)\end{array}$ & $\begin{array}{l}-0.0018 \\
(1.67)\end{array}$ & $\begin{array}{l}-0.0045 \\
(2.67)^{*}\end{array}$ & $\begin{array}{l}-0.0020 \\
(1.98)^{*}\end{array}$ & $\begin{array}{l}0.0001 \\
(0.17)\end{array}$ \\
\hline Tenure & $\begin{array}{l}-0.0043 \\
(2.25)^{*}\end{array}$ & & $\begin{array}{l}-0.0050 \\
(4.16)^{*}\end{array}$ & $\begin{array}{l}-0.0048 \\
(2.64)^{*}\end{array}$ & $\begin{array}{l}-0.0031 \\
(2.75)^{*}\end{array}$ & \\
\hline Lower secondary & $\begin{array}{l}0.0865 \\
(2.30)^{*}\end{array}$ & $\begin{array}{l}-0.3121 \\
(11.14)^{*}\end{array}$ & $\begin{array}{l}0.1359 \\
(4.80)^{*}\end{array}$ & & & \\
\hline Upper secondary & $\begin{array}{l}0.0061 \\
(0.15)\end{array}$ & $\begin{array}{l}-0.1420 \\
(5.54)^{*}\end{array}$ & $\begin{array}{l}0.0615 \\
(2.09)^{*}\end{array}$ & $\begin{array}{l}-0.0916 \\
(3.13)^{*}\end{array}$ & $\begin{array}{l}-0.0787 \\
(3.42)^{*}\end{array}$ & $\begin{array}{l}-0.1799 \\
(7.03)^{*}\end{array}$ \\
\hline Male & $\begin{array}{l}-0.0479 \\
(1.36)\end{array}$ & $\begin{array}{l}-0.0782 \\
(3.41)^{*}\end{array}$ & $\begin{array}{l}0.0031 \\
(0.15)\end{array}$ & $\begin{array}{l}-0.0533 \\
(1.83)\end{array}$ & $\begin{array}{l}0.0705 \\
(3.08)^{*}\end{array}$ & $\begin{array}{l}-0.0057 \\
(0.23)\end{array}$ \\
\hline Arts specialism & $\begin{array}{l}0.0624 \\
(1.37)\end{array}$ & $\begin{array}{l}-0.1587 \\
(3.86)^{*}\end{array}$ & $\begin{array}{l}0.1835 \\
(5.38)^{*}\end{array}$ & $\begin{array}{l}0.1891 \\
(3.65)^{*}\end{array}$ & $\begin{array}{l}0.1026 \\
(3.53)^{*}\end{array}$ & $\begin{array}{l}0.2031 \\
(5.77)^{*}\end{array}$ \\
\hline Social science specialism & $\begin{array}{l}0.1626 \\
(3.67)^{*}\end{array}$ & $\begin{array}{l}-0.0160 \\
(0.47)\end{array}$ & $\begin{array}{l}0.1327 \\
(4.24)^{*}\end{array}$ & $\begin{array}{l}0.2408 \\
(4.51)^{*}\end{array}$ & $\begin{array}{l}0.1536 \\
(5.08)^{*}\end{array}$ & $\begin{array}{l}0.1582 \\
(4.64)^{*}\end{array}$ \\
\hline Science specialism & $\begin{array}{l}0.1034 \\
(2.36)^{*}\end{array}$ & $\begin{array}{l}-0.1262 \\
(3.90)^{*}\end{array}$ & $\begin{array}{l}0.0636 \\
(2.51)^{*}\end{array}$ & $\begin{array}{l}0.1635 \\
(3.83)^{*}\end{array}$ & $\begin{array}{l}0.1232 \\
(4.44)^{*}\end{array}$ & $\begin{array}{l}0.1428 \\
(4.40)^{*}\end{array}$ \\
\hline Medical specialism & $\begin{array}{l}-0.0188 \\
(0.27)\end{array}$ & $\begin{array}{l}-0.2108 \\
(6.30)^{*}\end{array}$ & $\begin{array}{l}-0.0214 \\
(0.57)\end{array}$ & $\begin{array}{l}-0.0186 \\
(0.27)\end{array}$ & $\begin{array}{l}-0.1123 \\
(2.80)^{*}\end{array}$ & $\begin{array}{l}0.1290 \\
(3.33)^{*}\end{array}$ \\
\hline $\mathrm{N}$ & 3109 & 3269 & 3475 & 2051 & 3313 & 2841 \\
\hline Log-pseudolikelihood & -3.91 & -0.26 & -0.41 & -0.21 & -0.16 & -0.06 \\
\hline
\end{tabular}

This table reports marginal effects, with $\mathrm{z}$ values in parentheses, and an asterisk denoting significance at better than $5 \%$. For binary variables, the marginal effects reported are those associated with a change from zero to one; for continuous variables, the marginal effects are for a unit increase at the mean value. Numbers of respondents without qualifications are small in Italy, Japan and the USA, and so the excluded category of education includes lower secondary as well as those without qualifications. Other categorical variables excluded from this specification to preclude collinearity (and thus forming a baseline) are: manual occupations; working in small firms employing 10 workers or fewer; non-native workers; those for whom neither parent undertook higher education; and females. See also notes to Table 1 
appear to be an unusually high propensity for those educated to lower secondary level in France to report being overeducated.

The logit results (in both panels of the table) confirm our earlier findings that the incidence of overeducation tends to fall as occupational status increases. In countries where the relevant data are available, tenure with an employer serves significantly to reduce overeducation, significantly so in most cases. Once other factors are controlled for, gender appears to be a significant determinant of overeducation in two countries. Interestingly, though, the sign of the marginal effect differs across these countries, indicating that men are more likely than women to be overeducated in Japan, but less likely in Germany. The fall in the propensity to report being overeducated as firm size increases is apparent, at some levels at least, in most countries, but is not significant in the case of the UK or Germany. Native workers are significantly less likely to report themselves as overeducated than are immigrant workers in France, but the country of birth effect is not significant in any other country. Having at least one parent with higher education reduces the incidence of overeducation in the UK and Japan, but elsewhere the effects are insignificant.

The results reported in Panel B, for the most part, confirm that overeducation is more likely to be experienced by those schooled to higher levels. This is unsurprising inasmuch as such workers possess a greater stock of schooling that can be underutilised. The coefficient associated with a medical specialism is lower than that on the other subject variables in every country, reflecting the highly vocational nature of studies in this area - graduates of higher education programmes in medicine are less likely than other higher education graduates to experience overeducation. This effect is smallest in the United States.

Having examined the ways in which the incidence of self-reported overeducation varies with respondents' characteristics, we now proceed to investigate what effect this overeducation has on remuneration - and, by extension, on workers' productivity in the labour market. ${ }^{14}$ In so doing, we follow the lead of Duncan and Hoffman (1981). The received literature suggests that some, but not all, of the wage benefits of education are eradicated if a worker is overqualified for the job. Table 3 thus reports the results of regressions of the log hourly (gross) wage on a vector of explanatory variables typical of those used in the literature on earnings functions, including also binary indicators to signal whether or not the respondent is overeducated; two such indicators are used - one attaches to those respondents with higher education and the other to those who completed education at upper secondary level. ${ }^{15}$ The table reports equations for the UK, France, Italy and Japan, these being the countries for which wage data are available in PIAAC.

\footnotetext{
14 Kampelmann et al. (2016) have recently argued, and provided evidence to show, that where wages are largely standardised within an occupation (rather than being determined by worker characteristics) the impact of overeducation on productivity is likely to be greater than that on wages.

15 Mincer (1974) provides the framework for models of this kind. Following his work, statistical models designed to explain wages have almost universally included as explanatory variables measures of labour market experience, experience squared, and educational attainment. The rationale for the central role played by these variables is that they capture the acquisition of skills (or 'human capital') - either directly through instruction or by learning on-the-job. The dependent variable is logged in order to ensure that the model does not produce implausible negative predicted values of the wage; a further advantage of transforming the wage in this way is that the coefficients can be easily interpreted as the proportional
} 
Table 3 Wage equations (dependent variable is the log of the hourly gross wage)

\begin{tabular}{|c|c|c|c|c|}
\hline & UK & France & Italy & Japan \\
\hline Experience & $\begin{array}{l}0.0255 \\
(6.12)^{*}\end{array}$ & $\begin{array}{l}0.0272 \\
(11.08)^{*}\end{array}$ & $\begin{array}{l}0.0116 \\
(2.34)^{*}\end{array}$ & $\begin{array}{l}0.0211 \\
(5.87)^{*}\end{array}$ \\
\hline Experience $^{2}$ & $\begin{array}{l}-0.0004 \\
(4.48)^{*}\end{array}$ & $\begin{array}{l}-0.0004 \\
(6.26)^{*}\end{array}$ & $\begin{array}{l}-0.0001 \\
(0.41)\end{array}$ & $\begin{array}{l}-0.0002 \\
(2.86)^{*}\end{array}$ \\
\hline Higher education & $\begin{array}{c}0.6386 \\
(5.66)^{*}\end{array}$ & $\begin{array}{l}0.7362 \\
(5.59)^{*}\end{array}$ & $\begin{array}{l}0.4869 \\
(11.86)^{*}\end{array}$ & $\begin{array}{l}0.3150 \\
(6.95)^{*}\end{array}$ \\
\hline Upper secondary & $\begin{array}{c}0.2807 \\
(7.72)^{*}\end{array}$ & $\begin{array}{l}0.3982 \\
(3.04)^{*}\end{array}$ & $\begin{array}{l}0.1349 \\
(4.78)^{*}\end{array}$ & $\begin{array}{l}-0.0037 \\
(0.09)\end{array}$ \\
\hline Lower secondary & $\begin{array}{l}0.2120 \\
(5.89)^{*}\end{array}$ & $\begin{array}{l}0.3173 \\
(2.43)^{*}\end{array}$ & & \\
\hline Overeducated in higher ed. & $\begin{array}{l}-0.3831 \\
(3.15)^{*}\end{array}$ & $\begin{array}{l}-0.1301 \\
(5.01)^{*}\end{array}$ & $\begin{array}{l}-0.2131 \\
(3.48)^{*}\end{array}$ & $\begin{array}{l}-0.1985 \\
(5.74)^{*}\end{array}$ \\
\hline Overeducated in upper sec. & $\begin{array}{l}-0.0834 \\
(2.79)^{*}\end{array}$ & $\begin{array}{l}-0.0461 \\
(2.70)^{*}\end{array}$ & $\begin{array}{l}-0.1180 \\
(3.77)^{*}\end{array}$ & $\begin{array}{l}-0.0977 \\
(2.45)^{*}\end{array}$ \\
\hline Supervisor & $\begin{array}{l}0.1555 \\
(5.04)^{*}\end{array}$ & $\begin{array}{l}0.1275 \\
(8.61)^{*}\end{array}$ & $\begin{array}{l}0.1928 \\
(6.42)^{*}\end{array}$ & $\begin{array}{l}0.3478 \\
(12.16)^{*}\end{array}$ \\
\hline Firm size $11-50$ & $\begin{array}{l}0.0780 \\
(2.08)^{*}\end{array}$ & $\begin{array}{l}0.0495 \\
(2.42)^{*}\end{array}$ & $\begin{array}{l}0.1705 \\
(5.20)^{*}\end{array}$ & $\begin{array}{l}0.0923 \\
(2.28)^{*}\end{array}$ \\
\hline Firm size $51-250$ & $\begin{array}{l}0.1469 \\
(3.92)^{*}\end{array}$ & $\begin{array}{l}0.0997 \\
(4.67)^{*}\end{array}$ & $\begin{array}{l}0.2423 \\
(6.53)^{*}\end{array}$ & $\begin{array}{l}0.2001 \\
(5.40)^{*}\end{array}$ \\
\hline Firm size $251-1000$ & $\begin{array}{l}0.2404 \\
(4.47)^{*}\end{array}$ & $\begin{array}{l}0.1228 \\
(4.76)^{*}\end{array}$ & $\begin{array}{l}0.2097 \\
(4.35)^{*}\end{array}$ & $\begin{array}{l}0.3325 \\
(7.25)^{*}\end{array}$ \\
\hline Firm size over 1000 & $\begin{array}{l}0.2523 \\
(5.96)^{*}\end{array}$ & $\begin{array}{l}0.2293 \\
(7.54)^{*}\end{array}$ & $\begin{array}{l}0.2401 \\
(4.76)^{*}\end{array}$ & $\begin{array}{l}0.4818 \\
(7.45)^{*}\end{array}$ \\
\hline Constant & $\begin{array}{l}1.5479 \\
(27.60)^{*}\end{array}$ & $\begin{array}{l}1.6808 \\
(12.60)^{*}\end{array}$ & $\begin{array}{l}1.9923 \\
(43.98)^{*}\end{array}$ & $\begin{array}{l}6.6383 \\
(139.77)^{*}\end{array}$ \\
\hline $\mathrm{N}$ & 2962 & 3236 & 1696 & 3093 \\
\hline $\mathrm{R}^{2}$ & 0.1898 & 0.3039 & 0.3132 & 0.1839 \\
\hline
\end{tabular}

Dependent variable is the natural logarithm of the hourly wage. No data on wages are available for Germany or the USA. $\mathrm{t}$ values are in parentheses. See also notes to Table 2

The results are very much in line with those of other studies. There is an inverse$\mathrm{u}$ shaped relationship between experience and earnings, peaking at 32 and 34 years respectively in the UK and France. In Italy and Japan, meanwhile, the coefficients

\footnotetext{
Footnote 15 continued

increase in wage resulting from a unit change in the corresponding explanatory variable. In an earlier version of the paper, a series of dummy variables indicating respondents' occupations was also included in the set of explanatory variables; these are omitted here in order to avoid collinearity with the education variables, but we note that there was no qualitative difference in the results. In contrast to many other surveys, PIAAC has the benefit of a direct measure of employment experience (which is what we use here) - the relevant survey question is: 'In total, approximately how many years have you had paid work? Only include those years where 6 months or more was spent in either full-time or part-time work'.
} 
suggest that earnings rise monotonically with experience, with the curve becoming flatter at the top end of the age distribution. Higher levels of education result in higher wages in each country, though the impact on wages of secondary education in Japan is statistically insignificant. Supervising other workers results in a large premium on pay - particularly large in the case of Japan. Finally, there is a strong effect of firm size on wages, with larger firms paying more than smaller employers.

Of crucial importance in the context of this study is the coefficient on the 'overeducated' variables. In all countries, the wage effect of overeducation is negative. Importantly, however, in most countries, higher education graduates who deem themselves to be overeducated still receive, on average, a higher wage than do workers who quit education after secondary level. Education still adds to productive capacity and to remuneration, even if this education is surplus to the level required to do the job. This confirms the central finding of Duncan and Hoffman (1981), and cautions against interpreting overeducation as evidence of wasted investment. The United Kingdom is, however, an exception - here those who are overeducated do not appear to have a wage advantage over their colleagues. ${ }^{16}$ Of the countries studied here, it has, by some distance, the highest first time graduation rate, suggesting that there may indeed currently be an oversupply of graduates in that country (OECD 2016: 68).

Regressions of the kind reported above are based on best fit principles, and in effect describe the experience of a typical worker. Individuals who suffer a pay penalty associated with overeducation are, arguably, likely to be drawn from the tail of the distribution, however. Consequently, a quantile regression analysis is more likely (than an analysis of average behaviour) to pick up any deleterious effects of overeducation. ${ }^{17}$ To this end, we report in Table 4 the results of quantile regressions analogous to those reported in Table 3 . These confirm that, though there is some variation in coefficient magnitudes, the impact of overeducation is - at least in the case of France, Italy and Japan - small in relation to the gains that can be made from higher levels of education. We conclude therefore that, while many workers may have qualifications that exceed those required by their jobs, these workers are typically remunerated at higher levels than their colleagues who just satisfy the requirement - and that this result applies equally to workers who, by virtue of being in the tail of the distribution, are most likely to be overqualified.

While the results reported in Table 4 show how all coefficients in the model vary across the distribution, it is instructive to focus specifically on the coefficients on the overeducation variables - both for those with higher education and those with upper secondary education - and to study how these vary across all centiles of the wage distribution. These coefficients are shown graphically, by country, and for centiles

\footnotetext{
${ }^{16}$ In this case, for those with higher education, the fall in wage due to overeducation reduces the wage premium to a level below that attached to upper secondary education.

17 Quantile regression allows a regression line to be separately estimated at different points of the distribution of the dependent variable rather than, as in least squares regression, just at the mean. Comparison of the results at different quantiles allows us to assess the extent to which the impact of the explanatory variables on the dependent variable might vary across the distribution.. The idea of evaluating parameters at points other than the mean has a long history, but because the methods are computationally burdensome it is only recently that quantile regression has come to be commonly used. A good introduction is provided by Koenker and Hallock (2001). Applications in the context of overeducation include Martins and Pereira (2004) and McGuinness and Bennett (2007).
} 


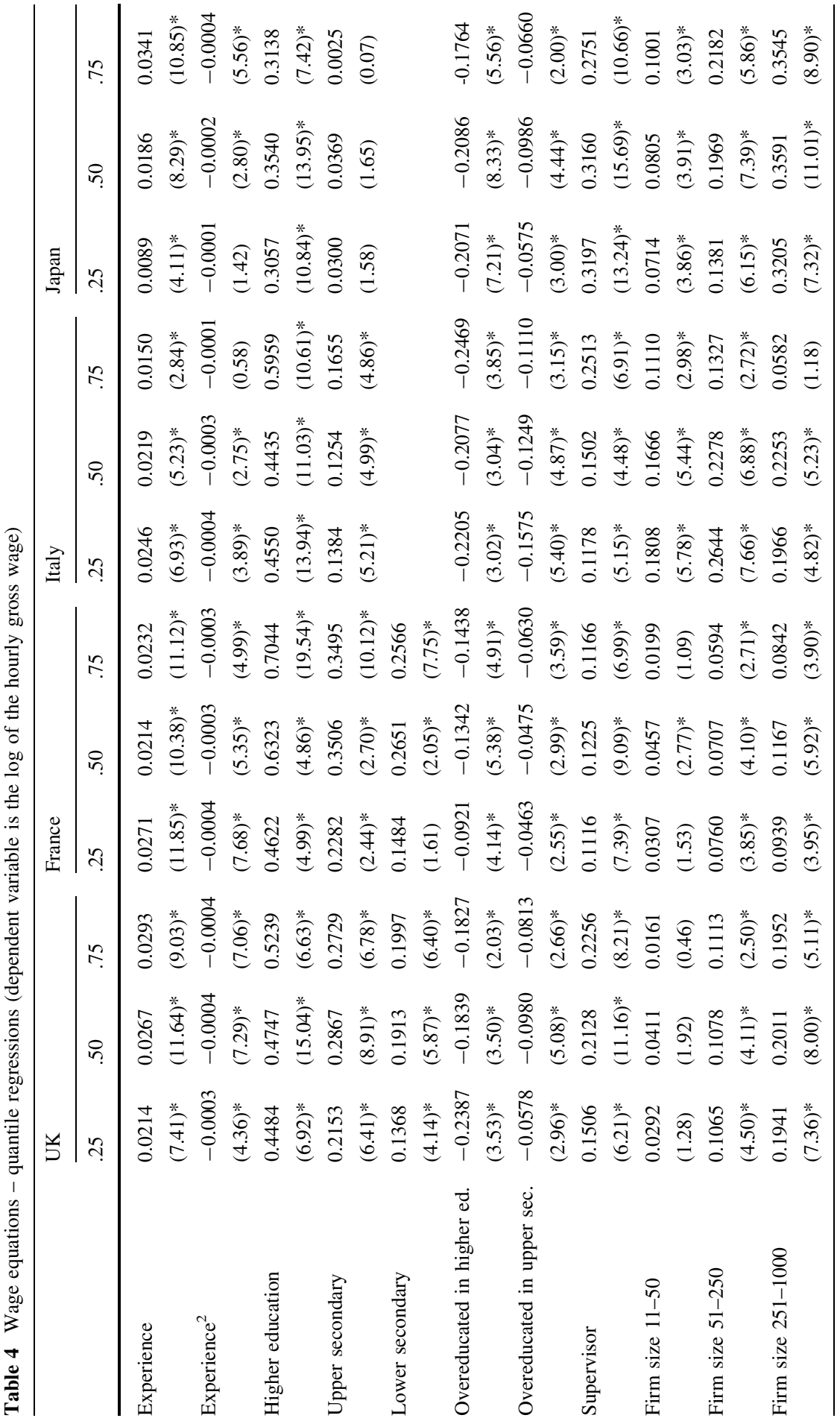




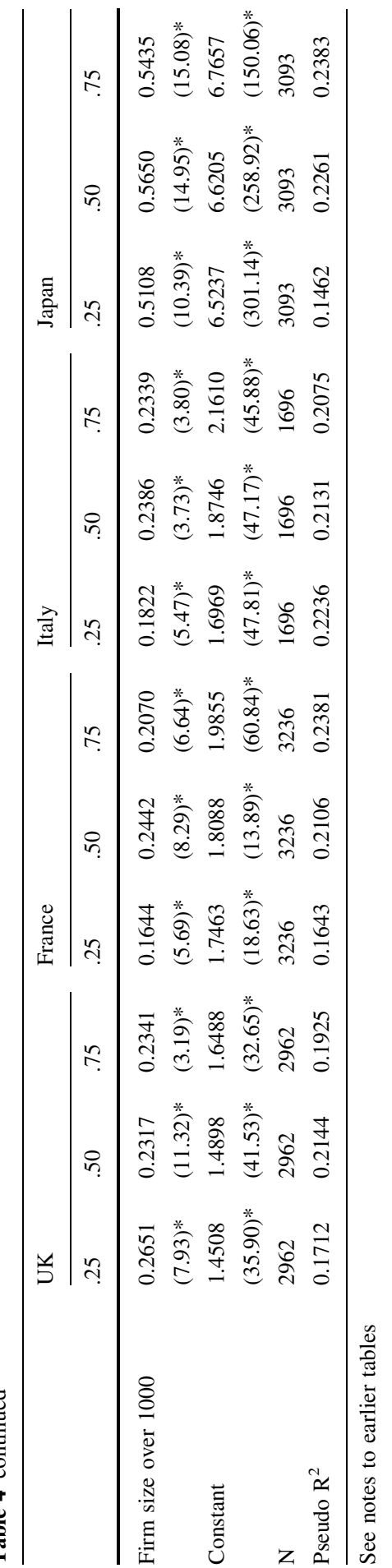




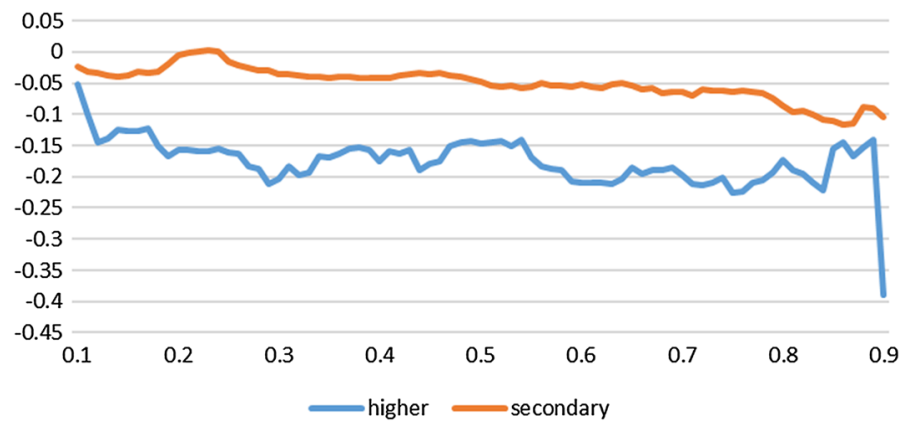

Fig. 1 Wage penalty to overeducation at each percentile of the wage distribution: UK

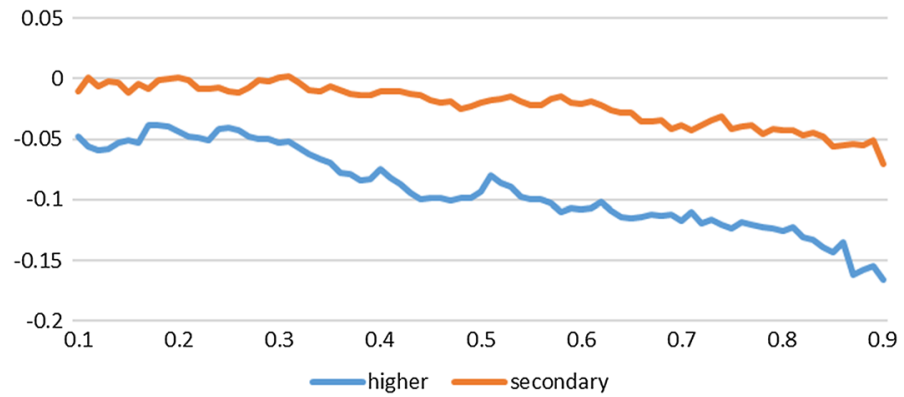

Fig. 2 Wage penalty to overeducation at each percentile of the wage distribution: France

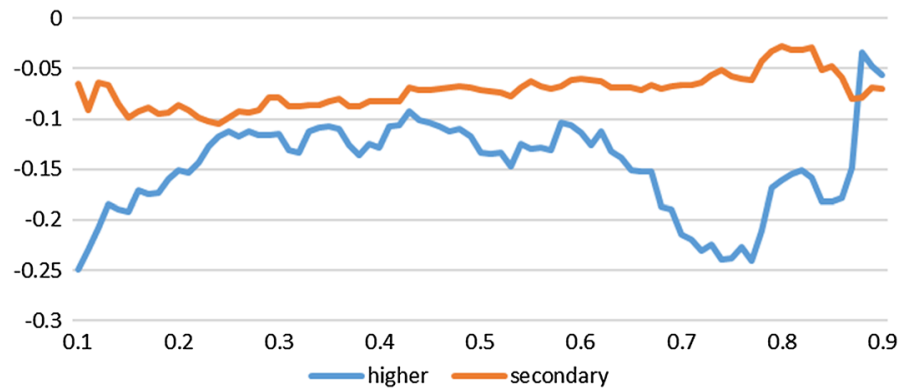

Fig. 3 Wage penalty to overeducation at each percentile of the wage distribution: Italy

between the 10th and 90th, in Figures 1, 2, 3 and 4. The results show marked differences across countries. In each country, the penalty associated with overeducation is, at almost all points, greater for those with higher education than for those with only upper secondary education; this is unsurprising since there is scope for a greater gap between the level of qualification and the demands of the job in the case of the former group. There is some evidence that in the UK and France those at the bottom end of the wage distribution suffer a smaller penalty than those 


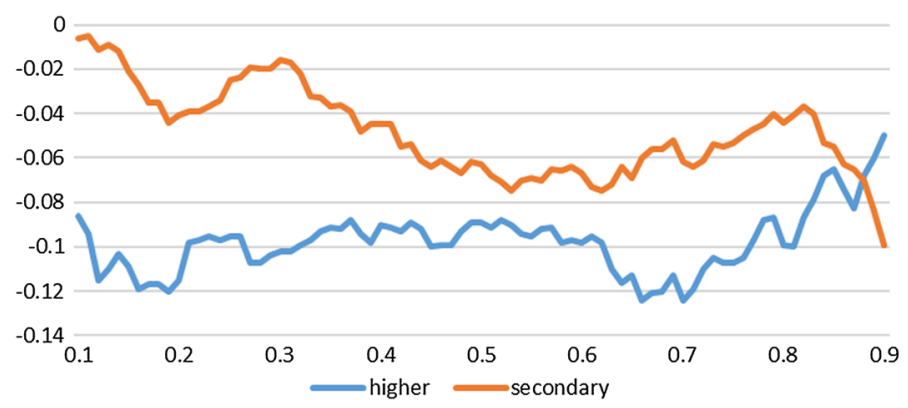

Fig. 4 Wage penalty to overeducation at each percentile of the wage distribution: Japan

at the top - in France the change is gradual, while in the UK the profile is quite flat except at the extremes. In Italy and Japan, meanwhile, the pattern of coefficients across the wage distribution is more complex. For those with higher education the coefficients follow an inverse-u shape (especially pronounced in Italy) - so that the pay penalty first falls and then rises as we move up the wage distribution. But beyond the 70th centile the pay penalty falls sharply. For workers in Japan whose highest qualification is at upper secondary level, the pattern of pay penalties due to overeducation is the reverse of this - first rising, then falling before rising sharply at the top end.

The variations across the distributions noted above are interesting, but should be viewed in the context of, for the most part, fairly low magnitudes of the pay penalties. The results for Italy are in some respects the most interesting. Recall that the incidence of overeducation in this country is relatively low. But Figure 3 shows that some of those who have received higher education and who are overeducated suffer a substantial pay penalty - notably those below the 15th centile and those between the 70th and 80th centiles. Low incidence of overeducation should not therefore necessarily imply that overeducation should not be a matter of concern.

\section{Conclusion}

The concept of overeducation generates considerable public and media interest, not least because it suggests a wasted investment. On a number of grounds, however, the extent of such waste is likely to be exaggerated by conventional measures. For reasons of data availability, the focus in existing studies (including the present one) is on the narrow economic returns to education, and wider social benefits are typically ignored. ${ }^{18}$ Furthermore, respondents to surveys may under-report the extent to which their education is useful in their jobs simply because they do not use all their learning in their work. Nevertheless, the regularities observed in the data tables reported above suggest that our measure of overeducation is capturing some real phenomenon, even though there is ambiguity about what that might be.

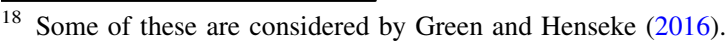


Moreover, even when viewed in purely economic terms, the concept of overeducation does not sit comfortably with mainstream models of the labour market. In the human capital model, individuals invest in education up to the point where the internal return falls to the level of returns obtainable through other investments, and their education contributes directly to increased productivity. It is not clear in this model why people should not invest rationally. There may be distortions to the market - for example, students may have limited information and hence make poor choices in deciding to prolong their education - but these are rarely pointed out as sources of overeducation, though arguably they should be. As participation rates in higher education have risen, many secondary school students have viewed progression to study at degree level as the norm, and their choice in continuing with their studies is arguably made in the absence of perfect information about returns (Rolfe 2002; Dill and Soo 2004).

In fact, the evidence suggests that in most contexts, where workers have qualifications that exceed those deemed necessary to undertake their jobs, the surplus education contributes to enhanced productivity. The results obtained in the present paper suggest that the UK may be an interesting and important exception and indeed the finding that it is exceptional serves to highlight the value of comparative study. In all the countries we have examined, however, surplus education does prove to be less productive than the education that is required to perform the job - there is a kink in the rate of return at the point of required education. The kink is worthy of study in its own right, since it indicates that overall productivity could be increased by reallocating workers to jobs that more closely suit their stock of human capital. The potential for social and economic benefits to be realised in this way has generally been underappreciated by policy-makers (McGuinness et al. 2017), and the work reported in the present study suggests a number of demographic determinants for the position of this kink relative to the stock of human capital that people have.

Of special interest - indeed the main novelty of this paper - is the extent to which the penalty attached to surplus education varies across workers, and the extent to which any such variation differs across countries. In particular, it is instructive to investigate whether workers at the bottom end of the distribution pay a higher penalty for overeducation than do others. Quantile regression analysis suggests that, for most countries analysed here, any such effect is either absent or minor; those with higher education in Italy are an important exception.

While overeducation is typically evaluated by reference to skills needed to perform tasks at work, the goals that society sets for education are broader. It is commonplace for politicians to make statements about what schools should or should not do, though these do not necessarily in any way connect to productivity at the workplace. $^{19}$ So long as there is tension between the way in which overeducation is evaluated and the goals set by society for education, it is inevitable that measures of overeducation will overstate the perceived 'problem'. Yet, given that they signal mismatch between the supply and demand for skills in

\footnotetext{
19 See, for example, http://www.pinknews.co.uk/2015/12/28/schools-should-teach-that-britain-is-achristian-country-says-nicky-morgan/.
} 
the labour market, and given that they do have implications for the efficiency of investment of real resource in education, the analysis of how these measures vary across demographics remains useful. The access that PIAAC gives to internationally comparable measures enhances our understanding of this phenomenon, and further analysis of updated PIAAC data is likely to prove fruitful in the future.

Acknowledgements Without implication, the author is grateful to two anonymous referees, to Tommaso Agasisti, and to seminar and conference participants at Maastricht and at Glasgow for helpful comments on an earlier draft.

Open Access This article is distributed under the terms of the Creative Commons Attribution 4.0 International License (http://creativecommons.org/licenses/by/4.0/), which permits unrestricted use, distribution, and reproduction in any medium, provided you give appropriate credit to the original author(s) and the source, provide a link to the Creative Commons license, and indicate if changes were made.

\section{References}

Abel, Jaison R., and Richard Deitz. 2016. Underemployment in the early careers of college graduates following the Great Recession, NBER working paper 22654.

Becker, Gary S. 1964. Human Capital. New York: Columbia University Press.

Bender, Keith A., and Kirsten Roche. 2017. Educational mismatch and the earnings distribution: Where does the mismatch bite? http://www.scotecon.org/pdf/2017/2017_26_Bender.pdf. Accessed 4 July 2018.

Berkson, Joseph. 1944. Application of the logistic function to bioassay. Journal of the American Statistical Association 39: 357-365.

Blanchflower, David G., and Andrew J. Oswald. 2011. International happiness: a new view on the measure of performance. Academy of Management Perspectives 24: 6-22.

Borghans, Lex, and Andries de Grip. 1999. Skills and low pay: upgrading or overeducation? Research Centre for Education and the Labour Market, Maastricht University, http://cris.maastrichtuniversity. n1/portal/files/611798/guid-214ee6f7-70fc-4226-a367-afb4a844fc60-ASSET1.0. Accessed 4 July 2018.

Brynin, Malcolm. 2002. Graduate density, gender and employment. British Journal of Sociology 53: 363-381.

Brynin, Malcolm, and Simonetta Longhi. 2009. Overqualification: Major or minor mismatch. Economics of Education Review 28: 114-121.

Caroleo, Floro Ernesto, and Francesco Pastore. 2017. Overeducation at a glance: Determinants and wage effects of the educational mismatch based on AlmaLaurea data. Social Indicators Research, forthcoming.

Dill, David, and Maarja Soo. 2004. Transparency and quality in higher education markets. In Markets in Higher Education: Rhetoric or Reality?, eds. Pedro Teixeira, Ben Jongbloed, David Dill, and Alberto Amaral, 61-86. Dordrecht: Kluwer.

Di Pietro, Giorgio, and Peter Urwin. 2006. Education and skills mismatch in the Italian graduate labour market. Applied Economics 38: 79-93.

Dolton, Peter J., and Anna Vignoles. 2000. The incidence and effects of overeducation in the UK graduate labour market. Economics of Education Review 19: 179-198.

Dolton, Peter J., and Mary Silles. 2008. The effects of overeducation on earnings in the graduate labour market. Economics of Education Review 27: 125-139.

Duncan, Greg J., and Saul D. Hoffman. 1981. The incidence and wage effects of overeducation. Economics of Education Review 1: 75-86.

Flisi, Sara, Valentina Goglio, Elena Claudia Meroni, Margarida Rodrigues, and Esperanza Vera-Toscano. 2014. Measuring occupational mismatch: overeducation and overskill in Europe: Evidence from PIAAC, http://www.aiel.it/Old/bacheca/Pisa/papers/Flisi.pdf. Accessed 4 July 2018. 
Foley, Beth, and Ian Brinkley. 2015. Unemployed and overqualified: Graduates in the UK labour market, London: The Work Foundation, http://bit.ly/2fAuq8t. Accessed 4 July 2018.

Freeman, Richard. 1976. The Overeducated American. New York: American Press.

Gaeta, Giuseppe Lucio. 2015. Was it worth it? An empirical analysis of overeducation among $\mathrm{PhD}$ recipients in Italy. International Journal of Social Economics 42: 222-238.

Gaeta, Giuseppe Lucio, Giuseppe Lubrano Lavadera and Francesco Pastore. 2018. Overeducation wage penalty among PhD holders: An unconditional quantile regression analysis on Italian data, IZA discussion paper 11325, http://ftp.iza.org/dp11325.pdf. Accessed 4 July 2018.

Green, Francis, and Golo Henseke. 2016. Should governments of OECD countries worry about graduate overeducation? Oxford Review of Economic Policy 32(4): 514-537.

Green, Francis, and Steve McIntosh. 2007. Is there a genuine underutilization of skills among the overqualified. Applied Economics 39: 427-439.

Green, Francis, Steve McIntosh, and Anna Vignoles. 1999. Overeducation and skills - clarifying the concepts, http://cep.lse.ac.uk/pubs/download/dp0435.pdf. Accessed 4 July 2018.

Groot, Wim, and Henriëtte Maassen van den Brink. 2000. Overeducation in the labor market: A metaanalysis. Economics of Education Review 19: 149-158.

Hartog, Joop. 1985. Earnings functions; testing for the demand side. Economics Letters 19: 281-285.

Holmes, Craig, and Ken Mayhew. 2015. Overqualification and skills mismatch in the graduate labour market. London: Chartered Institute of Personnel Development, http://bit.ly/2fXPIxC. Accessed 4 July 2018.

Iammarino, Simona, and Elisabetta Marinelli. 2015. Education-job (mis)match and interregional migration: Italian university graduates' transition to work. Regional Studies 49: 866-882.

Kampelmann, Stephan, Benoit Mahy, Francois Rycx and Guillaume Vermeylen. 2016. Who is your perfect match? Educational norms, educational mismatch and firm profitability, IZA DP 10399, available at http://ftp.iza.org/dp10399.pdf. Accessed 4 July 2018.

Koenker, Roger, and Kevin F. Hallock. 2001. Quantile regression. Journal of Economic Perspectives 15: $143-156$.

Leuven, Edwin, and Hessel Oosterbeek. 2011. Overeducation and mismatch in the labor market. In Handbook of the Economics of Education, vol. 4, eds. Eric Hanushek and Steve Machin, 283-326. Amsterdam: Elsevier.

Locke, John. 1692. Some Thoughts Concerning Education, http://oll.libertyfund.org/titles/locke-theworks-vol-8-some-thoughts-concerning-education-posthumous-works-familiar-letters. Accessed 4 July 2018.

Maier, Michael, Friedhelp Pfeiffer, and Winfried Pohlmeier. 2003. Overeducation and individual heterogeneity. In Overeducation in Europe: Current Issues in Theory and Policy, eds. Felix Büchel, Andries de Grip, and Antje Mertens, 133-154. Cheltenham: Edward Elgar.

Martins, Pedro S., and Pedro Telhado Pereira. 2004. Does education reduce wage inequality? Quantile regression evidence from 16 countries. Labour Economics 11: 355-371.

McGuinness, Séamus. 2006. Overeducation in the labour market. Journal of Economic Surveys 20: 387-418.

McGuinness, Séamus, and Jessica Bennett. 2007. Overeducation in the graduate labour market: A quantile regression approach. Economics of Education Review 26: 521-531.

McGuinness, Séamus, Konstantinos Pouliakas, and Paul Redmond. 2017. How useful is the concept of skills mismatch?, IZA Discussion Paper 10786, http://ftp.iza.org/dp10786.pdf. Accessed 4 July 2018.

McMahon, Walter. 2009. Higher Learning, Greater Good; the Private and Social Benefits of Higher Education. Baltimore: Johns Hopkins University Press.

Mincer, Jacob. 1974. Schooling, Experience and Earnings. New York: Columbia University Press.

Montenegro, Claudio E., and Harry Anthony Patrinos. 2014. Comparable estimates of returns to schooling around the world, World Bank Policy Research Working Paper 7020.

Nieto, Sandra. 2014. Overeducation, skills and the wage penalty: Evidence for Spain using PIAAC data, http://www.ub.edu/irea/working_papers/2014/201411.pdf. Accessed 4 July 2018.

OECD. 2012. Employment Outlook, Paris: OECD, available at http://bit.ly/2fyqchG. Accessed 4 July 2018.

OECD. 2016. Education at a Glance, Paris: OECD, available at http://bit.ly/2fN57Dt. Accessed 4 July 2018.

Pastore, Francesco. 2017. Why so slow? The school-to-work transition in Italy, IZA Discussion Paper 10767, http://ftp.iza.org/dp10767.pdf. Accessed 4 July 2018. 
Rolfe, Heather. 2002. Students' demands and expectations in an age of reduced financial support: The perspectives of lecturers in four English universities. Journal of Higher Education Policy and Management 24: 171-182.

Rumberger, Russell. 1987. The impact of surplus schooling on productivity and earnings. Journal of Human Resources 22: 24-50.

Schultz, Theodore. 1961. Investment in human capital. American Economic Review 51: 1-17.

Sicherman, Nachum. 1991. Overeducation in the labor market. Journal of Labor Economics 9: 101-122.

Son, Joonmo, and John Wilson. 2011. Generativity and volunteering. Sociological Forum 26: 644-667.

van der Meer, Peter H. 2006. The validity of two education requirement measures. Economics of Education Review 25: 211-219.

Verdugo, Richard, and Naomi Verdugo. 1989. The impact of surplus schooling on earnings: Some additional findings. Journal of Human Resources 24: 629-643.

Walker, Ian, and Yu Zhu. 2011. Differences by degree: Evidence of the net financial rates of return to undergraduate study for England and Wales. Economics of Education Review 30: 1177-1186. 